\title{
The Filmī'Ilmī Formula: Shama Magazine and the Urdu Cosmopolis
}

\author{
Afroz Taj \\ Associate Professor of South Asian Studies, Department of Asian Studies, \\ University of North Carolina, Chapel Hill, North Carolina \\ taj@unc.edu
}

\begin{abstract}
This article traces the history and significance of Shama (Sham') magazine in the context of Urdu popular culture in the twentieth century. Published monthly from 1939 to 1999, Shama developed a successful filmi-'ilmī (film and belles-lettres) formula that made it the most widely circulated Urdu monthly in India for half a century. I analyze Shama's components and publishing strategies, drawing on archival evidence, interviews, and personal testimony. Building on work by Jennifer Dubrow, Francesca Orsini, and others, I argue that Shama played an important role in defining the postIndependence Urdu public. While Shama purported to cater to male readership, visual and textual evidence suggests that the Shama community also included a "secret" readership of women. I further argue that Shama's cover paintings, and the juxtaposition of text and image within, embody some of the contradictions of the mid-twentiethcentury Urdu cosmopolis.
\end{abstract}

\section{Keywords}

Shama (Sham) magazine - Urdu periodicals - Urdu public - readership - India

In casual English, "publication" means making something public, or available to the reading public. "Publication" could also mean creating a public, that is, forming and articulating a particular public with delineable characteristics. In 
this paper I argue that Shama (Candle) magazine, ${ }^{1}$ published monthly for six decades from 1939 until 1999, articulated a public that was socially and historically significant in the context of twentieth-century South Asian cultural studies.

The notion of the "Urdu public" is derived from recent work by Francesca Orsini, Jennifer Dubrow, and others. Orsini's study of the Hindi public sphere follows Jürgen Habermas, who delineated the existence of an emerging public sphere in early modern Europe. ${ }^{2}$ In Habermas's formation, the public acts separately from the state; indeed, facilitated by the press and educational institutions, the public may debate, criticize and offer resistance to state policies. Orsini discusses how Hindi started as an underdog language, with respect to Urdu, in the later nineteenth century in British India, but by leveraging print capitalism it was able to rise to dominance by the time of Independence. There is no space here to discuss the complex historical relationships of the Hindi and Urdu public spheres, but suffice it to say that they overlapped and competed for resources and official sanction. By Independence in 1947, Hindi had been adopted by the government, but Urdu still clung to its position as the secular, progressive language of literature and films. Arvind Rajagopal carries Orsini's argument into the present with a discussion of what he terms the "national-popular" in India and how the film industry was often at odds with the government about the construction of a national culture. ${ }^{3}$

For the case of Urdu, Dubrow elaborates this concept of an Urdu public using the term "Urdu cosmopolis":

The Urdu cosmopolis acted to resist the fractures of religious communalism - political forms that relied on religion as a "hard" marker of identity—and incipient nationalism. Against this backdrop, the actions of members of the Urdu cosmopolis to claim a shared space and affiliation on the basis of language, rather than religion, region, caste, or class, became an act of resistance, the construction of a cosmopolitan ideal that was soon challenged, yet revived in other forms and other locations. ${ }^{4}$

1 For convenience, throughout this article I will use the English title Shama rather than the transliteration from the Urdu (Sham) because the former was found on the cover page of each issue along with the title in Urdu script. I will also not transliterate the titles of films and names of celebrities that appeared prominently in the English language press (e.g., Nutan, Jogan, etc.).

2 Orsini, The Hindi Public Sphere 1920-1940. Orsini cites Habermas, The Structural Transformation of the Public Sphere.

3 Rajagopal, The Indian Public Sphere.

4 Dubrow, Cosmopolitan Dreams, viii. 
This Urdu cosmopolis was constituted in large part through the action of print media, in which modes of modernity are negotiated, shared values are propagated, and the proverbial mirror is held up to society. Dubrow argues that it was this process of self-reflexivity mediated by print capitalism that generated the progressive movements that emerged from the Urdu cosmopolis. In a similar vein, Javed Majeed writes that "the Urdu periodical press became an object for itself to reflect upon..5 Majeed is talking about Urdu journals of the late nineteenth century, but his comments apply equally well to the twentieth century, especially during and after the upheavals of Partition. I argue that one of the aims of this self-reflection was to articulate modernity for the Urdu public at large.

One of the central questions of modernity is how women participate in the public sphere. Javed Majeed ${ }^{6}$ and Gail Minault ${ }^{7}$ discuss the ways in which the nineteenth-century Urdu periodical press promoted women's education at the intersection of religion, nationalism, and anti-colonialism. In one of the few studies of twentieth-century Urdu women's periodicals, Nadia Siddiqui concludes that even in their more popular manifestations, women's magazines in Urdu were understood by their readers to have an educational objective, giving women access to the world beyond the limits of their domestic sphere. This was complicated, however, by mothers' fears about their daughters being deluded by unrealistically romantic portrayals of love and marriage. ${ }^{8}$

The geographically diffuse Urdu reading public is better conceived as a network than a bounded space. Major cities like Delhi, Bombay, Hyderabad, Lucknow, Lahore, and Karachi were nodes in the network, but there were significant populations of Urdu speakers in cities and towns throughout the belt stretching across the breadth of northern India and Pakistan. It is evidence of Urdu's long-time role as the South Asian lingua franca that Urdu readers were - and still are-found far outside Urdu's homeland(s). ${ }^{9}$ For example, I came upon a large trove of Shama magazines recently in Chennai, Tamil Nadu.

The Urdu public was defined by much more than the ability to read the Urdu script (Nastalīq), but as we shall see in Shama, the script was used as a synecdoche for a cultural complex that encompassed literature, music, and other arts, as well as a shared habitus. Other characteristics of this Urdu reading public, including its tastes and attitudes toward gender and religion, will

5 Majeed, "Narratives of Progress," 136.

6 Majeed, "Narratives of Progress," 139.

7 Minault, Secluded Scholars, $105 \mathrm{ff}$.

8 Siddiqui, "Who Reads Urdu Women's Magazines and Why?," 323-34.

9 A history of the changes in Urdu geography after Partition, of post-1947 language politics in India and Pakistan, and of Urdu's role in the South Asian diaspora, is beyond the scope of this paper. 
be discovered as we explore the history, content, and imagery of Shama itself. This exploration is based on close textual and visual readings of the magazine across its sixty-year publication history, ${ }^{10}$ extensive interviews with the Dehlvi family and Shama's readers, and my personal testimony.

\section{Lighting the Candle}

Shama (Candle) was founded in 1939 by Yusuf Dehlvi. The origin of Shama, or rather its origin myth, reveals a peculiar form of cultural hybridity that was to characterize the magazine itself, as well as its readership and the Urdu public it engendered. According to Yusuf's eldest son, Younus, the family traces its roots to the Punjabi city of Multan, a renowned center of Sufi culture. At some point in the nineteenth century, one scion of this family settled in Shāhjahānābād (Old Delhi) in the area now called Habash Khan and took on the "Dehlvi" surname. The family retained its allegiance to its Sufi pir silsilah (master's lineage) while becoming major leather dealers and investing in real estate. ${ }^{11}$

When Shama began publication in 1939, it was conceived as a combination religious and literary magazine, with a fairly conservative editorial policy reflecting the Muslim piety of Yusuf Dehlvi and his family. According to Younus, it was his father Yusuf's pìr 'Azìz ur-Raḥmān Pānīpatī himself who first suggested that he replace the religious component of the magazine with material on "bioscope," the Urdu-Hindi film industry. ${ }^{12}$ The apparent contradiction between the Sufi persona of the editor and the perceived moral ambiguity of the film industry was cultivated by Shama and occasionally by other film magazines like Muṣavvir that also contained literature and literary criticism. ${ }^{13}$ On one hand, the promise of juicy gossip about stars' love lives helped sell the magazine, while on the other hand, the moral unimpeachability of Yusuf Dehlvi, his family, and the belles-lettres component of the journal helped lend

10 Over the past twenty years I have amassed a large — but still incomplete-collection of Shama and its offshoots (Bāno, Khilaunā, Shabistān, etc.). With a very few exceptions, Shama was not collected in libraries. My collection was assembled from used bookstores, friends' attics, and Sunday pavement book markets in many of India and Pakistan's major cities.

11 Most of my information about the Dehlvi family and the origins of Shama comes from two unpublished interviews with Younus Dehlvi himself (July 2015 and July 2017, Gurgaon, India), supplemented by personal communications from other members of the Dehlvi family and former Shama employees.

12 Younus Dehlvi, personal communication to author, interview July 21, 2015. Unfortunately, I have no additional information about 'Azīz ur-Rahmān Pānīpatī.

13 Yusuf Dehlvi was sometimes portrayed in the magazine wearing a Muslim skull cap. 
a degree of respectability to the film industry. Indeed, Shama never indulged in cheap scandal mongering like some of its competitors. ${ }^{14}$

Shama maintained its hybrid identity throughout its existence; I call this hybrid identity the "filmī'ilmī (cinematic-scientific) formula." Filmī is a somewhat disparaging term for anything related to the world of cinema, while ilmi comes from the Urdu-Arabic 'ilm, connoting scientific knowledge in general or any subfield thereof, including belles-lettres or religious knowledge. As the twentieth century progressed, it was this underlying tension between Shama's film-industry livelihood and its appeal to the Muslim intelligentsia that drove its popularity.

Shama was by no means the only magazine that focused on emerging Indian cinema. The 1920 s and 1930 s had witnessed the birth of the Indian film journalism industry and in addition to features and columns in daily newspapers, 68 film journals were in print by $1938 .{ }^{15}$ These journals were published primarily in English or Urdu, in the major film production centers of Bombay, Calcutta, and Lahore, as well as in the colonial capital, Delhi. ${ }^{16}$ Debashree Mukherjee argues that while early film journalism took on diverse forms ranging from scandal columns to critical reviews, it participated in the construction of modernity by relating film to social issues of concern in pre- and post-Independence India. ${ }^{17}$ Shama, by virtue of its hybrid format, asserted the pivotal role of the film industry in constructing the Urdu cosmopolis and defining South Asian modernity.

Yusuf Dehlvi's adoption of the filmī-ilmì formula makes sense on a number of levels. The relationship between literature and film is buttressed by the Indian film industry's extensive use of poetry in the form of song lyrics, as well as the practice of basing film screenplays on novels and plays. Many of the writers whose poems and short stories were published in Shama also worked in the film industry. But at another level, this duality underscores one of the

14 For a discussion of some notable scandals in the film industry press, see Mukherjee, "Notes on a Scandal," 9-3o.

15 Mukherjee, "Creating Cinema's Reading Publics," 169.

16 These included Mauj Majah (Gujarati, Bombay, est. 1924), Cinema (Urdu, Lahore, est. 1925), Varieties Weekly (English, Calcutta, est. 1931), Rañg Bhūmī (Hindi, Delhi, est. 1931), Chitrā (Urdu, Lahore, est. 1934), filmindia (English, Bombay, 1935-1961), and Mușavvir (Urdu, Bombay), edited for a time by Saādat Ḥasan Manțo. Additional titles from this era are mentioned in Mukherjee, "Creating Cinema's Reading Publics," and Abbasi, "The Lost World of Urdu Film Magazines." These include Film Art (Delhi), Film Stage (Calcutta), Filmland (Calcutta), Mirror (Bombay), Sound (Bombay), Shabistān (Lahore), Tașvìr (Urdu, Lahore), Star (Urdu, Lahore), and Film-kār (Urdu, Lahore). I have given dates of publication, location, and language only where known.

17 Mukherjee, "Creating Cinema's Reading Publics" 178-80. 
main contradictions inherent in Indian modernity: the tension between popular culture and the progressive literary movement. We will encounter this contradiction in Shama both in its content and its cover paintings.

Three generations of Dehlvis were involved in Shama's management: Yusuf, the founder; his three sons, Younus, Idrees, and Ilyas; as well as some of their wives and children. Despite the dynastic corporate structure, Shama was the first monthly Indian journal of any kind in any language to surpass the 100,ooo-subscribers milestone, which it did, according to Younus, as early as 1949. Shama's peak circulation is unknown: the company's financial records did not survive the closing of the Shama office in 1999. Shama's early commercial success led to a number of spin-off publications under the Shama umbrella. These included Bāno (Lady), a magazine specifically for women, Khilauna (Toy) for children, the crime/spy magazine Mujrim (Criminal), and others. Several magazines were patterned after successful American magazines, including Á'inah (Mirror), a copy-cat version of Life, and Shabistān (Bedroom), an imitation of Reader's Digest.

In the 195os and 196os, Shama and the film industry were growing in tandem, symbiotically. As the Urdu-Hindi cinema entered its post-independence golden era, Shama reviewed, discussed, and promoted films and film culture. Indian popular cinema only began to be taken seriously by scholars and cultural analysts at the turn of the twenty-first century; Shama was decades ahead of its time with its critical articles about films. For Shama's readers, films mattered: they were connected intimately with literature, with culture, with issues of gender, caste, class, and creed. Yusuf Dehlvi's strategy was not merely to make Shama racy with filmi scandals: he struck and maintained the balance between film and 'ilm, between entertainment and knowledge, and made the two intersect. On the one hand, the filmi content made Shama appear more lowbrow than its literary competitors, but on the other hand, Shama's critical relationship with the film industry exemplified the self-reflective process of modernity.

Like Urdu novels and newspapers, Urdu monthly magazines had been around since the mid-nineteenth century. Many such magazines used what Gail Minault has termed the "masala formula,"18 referring to the way in which such magazines combined practical information, news, and literary writing in each issue. Shama employed this formula despite the changing terrain of Urdu periodical publishing in the decade before Independence, successfully competing against a number of challengers. First among Shama's competitors was the highbrow literary journal Bīsvĩn Șadī (Twentieth Century), which began 
publication just months before Shama. Even though it published many of the same authors who appeared in Bīsviñ Șadī, Shama was perceived as being more middlebrow, catering more to popular tastes; Bissvĩn Șadī largely eschewed the film industry. Eventually other rival magazines emerged to focus exclusively on the film industry and its salacious scandals; these catered to the lowbrow end of the readership spectrum.

More challenging to Shama's prosperity, perhaps, was the slow transformation of the public's perception of the Urdu language itself, from the dominant lingua franca and literary language of South Asia to the marginalized language of a religious minority. I argue that Shama was able to weather this sea change precisely because it held firmly to its risqué — albeit middlebrow—image, and its ability to court a wide readership by deploying its trademark hybrid formula. Indeed, many of my interlocutors testify to the fact that Urdu was able to retain its secular, cosmopolitan associations into the twenty-first century largely through the intervention of Shama magazine.

While Shama itself was a hybrid, Yusuf Dehlvi realized quickly that there were other adjacent niches to be exploited. In the early 1950s he acquired Bāno and used the Shama name to leverage it into India's premiere women's

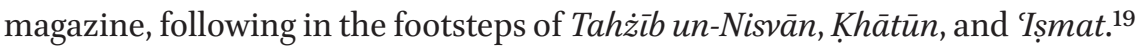
Bāno contained content similar to the nineteenth century magazines, a mixture of practical knowledge and literature, but without Shama's film focus and the risqué image. At nearly the same time, the children's magazine Khilauna was launched. Unlike the moralistic children's magazines from the nineteenth century, Khilauna treated its young readers as friends, and the magazine was meant to be played with, not merely read. It published fiction and informational articles drawn from cosmopolitan sources, as well as baby pictures submitted by readers. Barely out of college, Khilaunā editor Yusuf's youngest son, Ilyas Dehlvi, enlisted highly reputed writers like Ḳhvājah Aḥmad 'Abbās, Krishan Chandar (Krishan Chander) and Rājindar Singh Bedī to contribute children's stories. Khilaunā also contained illustrated serialized comic strips which contained some of India's first homegrown fantasy and science fiction for children.

As Urdu readership slowly declined through the 196os, the Dehlvis launched a Hindi version of Shama, called Sushamā (Splendour); the name was chosen because of the phonemic similarity. In retrospect, this marketing concession to the nationalist project of establishing Hindi as the primary official language of India may have marked the beginning of the end for Shama and Sushama alike: the Shama brand was too closely intertwined with Urdu. When I asked

19 As described in Minault, Secluded Scholars, $105 \mathrm{ff}$. 
Younus Dehlvi about his family's role in promoting Urdu and sustaining the Urdu reading public through the twentieth century, he laughed and told me that for them it was just a business. They were entrepreneurs, and as long as the Urdu public remained faithful, their magazines survived: "We didn't even know that we were serving the language. When people said this, we answered, 'As you like.' Our attention was elsewhere."20

At the time of its collapse in 1999, the Shama empire included nine monthly publications: four Urdu/Hindi pairs (Shama/Sushamā, Bāno/Sushmitā, Khilaunā/Dost aur Dostī, Mujrim/Doshī) and the digest Shabistān. The offices were closed when the business failed and were inhabited only by monkeys and drug addicts for almost twenty years. Figure 1 shows the defunct Shama offices in Kamla Market, Ajmeri Gate, Asaf Ali Road, Delhi. ${ }^{21}$ Note the signs on the first floor above ground level (see Figure 2 for a closer image). It was only in August 2018 when the offices were temporarily reopened so that Mohsin Dehlvi could remove any remaining Shama materials (see Figure 3). Most of the hardware had been stolen but Mohsin was able to salvage some of the back issues of various magazines as well as a large pile of photographs. ${ }^{22}$

Let us look more closely at the relationship between Shama's readership and the actual content—visual and textual—of the magazine itself. Throughout its existence, Shama presented certain contradictions deriving from its hybrid origins. On the one hand, the magazine reflected popular tastes and attitudes

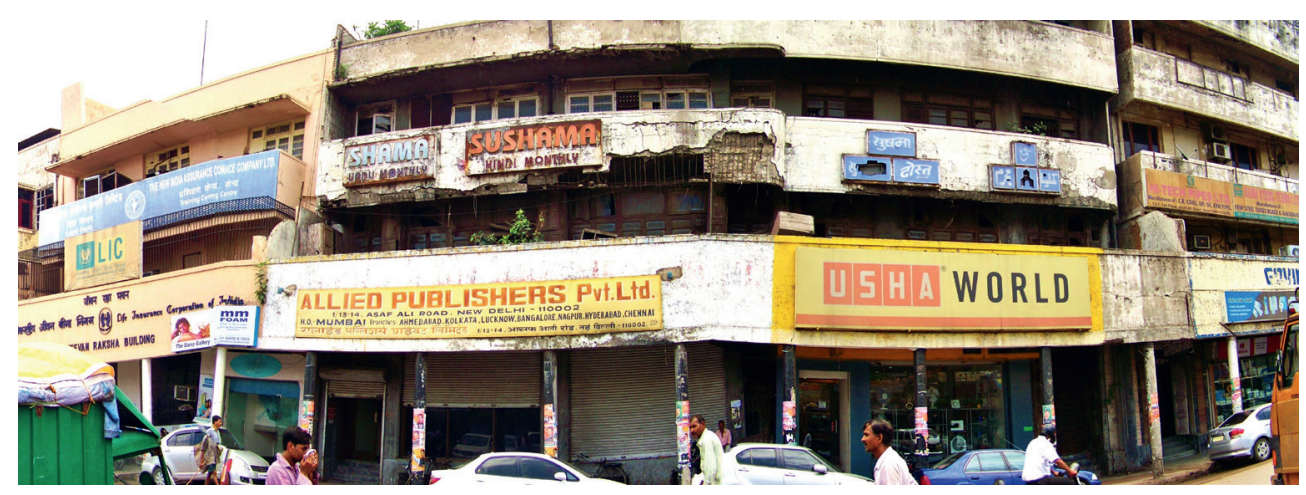

FIGURE 1 Abandoned Shama Offices (middle story) as they looked in 2017, Kamla Market, Delhi

20 Younus Dehlvi, personal communication to author, interview July 16, 2017.

21 All photos in this article are taken by me unless otherwise noted. The scans of Shama are also by me, from issues in my private collection.

22 I am eternally indebted to Mohsin for his kindness and generosity. He conveyed most of the material from the Shama offices to me for my research. 


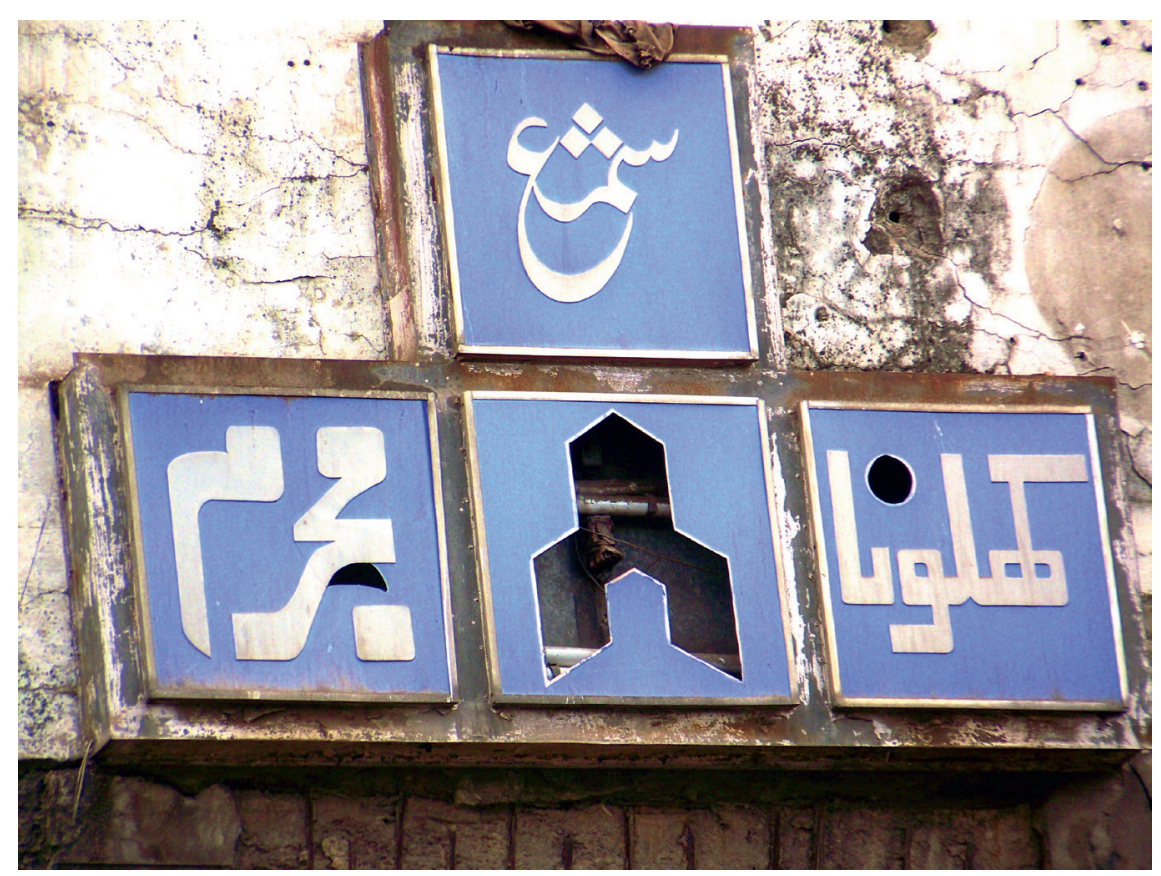

FIGURE 2 Detail of storefront of abandoned Shama Office. Each magazine had its distinctive logo taking advantage of Urdu's calligraphic potential (the rocket-shaped hole in the bottom center was the Bāno logo)

as held in common by its readership over multiple generations. On the other hand, Shama was perceived as pushing against the norms of "decent society" with its titillating fiction, risqué illustrations, and juicy gossip about Bollywood stars. According to my own memory and the testimony of multiple interlocutors, it was not considered a decent publication for "good girls" to read. At one point, my elder brother took on the responsibility of censoring the questionable material: he would spend hours excising the filmi content, saving and collating only the ghazals and short stories. But within the burgeoning Urdu-speaking middle class, it seems that everyone read it, even if women and children had to read it secretly. I hypothesize that part of the reason for this taboo was the nature of the cover paintings.

In terms of readership, marketing, and branding, the cover pages of Shama raise a basic question: Can the images on the cover be read to represent the 


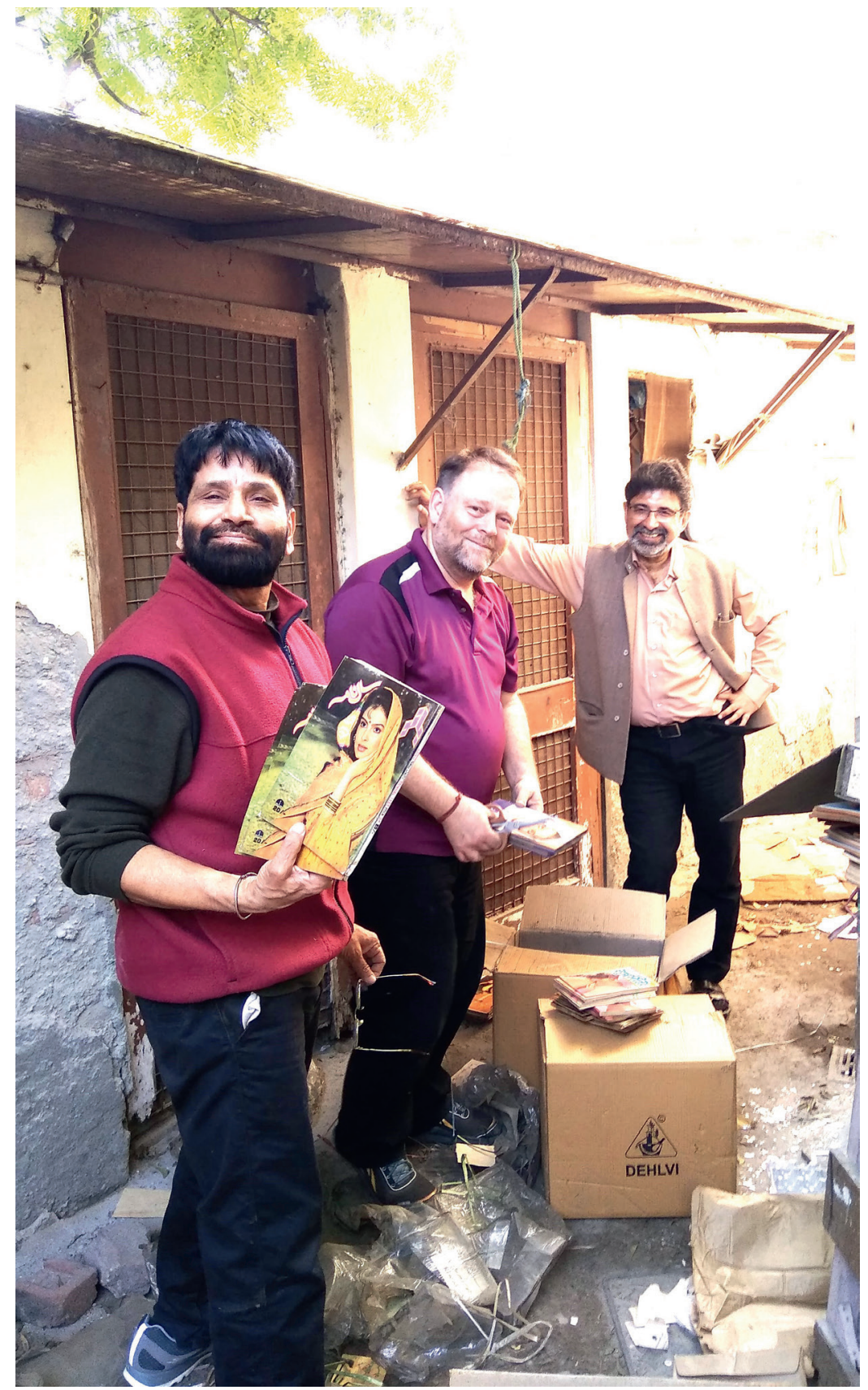

FIGURE 3 The author with Mohsin Dehlvi and John Caldwell opening boxes of materials rescued from the Shama Office 
content, and if so, how? Throughout most of its history, each Shama cover page consisted of a painting of a woman. In the early decades, these women were painted to resemble fairies-wings and all—while in the 1950s, 196os, and 1970 , the paintings were of young, fashionable, "modern" women. In the 1980 os and beyond, the covers featured color photographs of actresses and actors from Urdu-Hindi cinema.

The Shama cover paintings fall generally into the category of commodified " $b \bar{a} z \bar{a} r$ art," which has been theorized extensively by Patricia Uberoi, Kajri Jain, Christopher Pinney, Yousuf Saeed, and others. Uberoi, Jain, and Pinney focus primarily on Hindu calendar art while Saeed has written about Muslim devotional art. Although the Shama covers are not devotional in any sense, they do participate in the discourses of modernity and community articulated in these scholars' work. Uberoi makes the important point that these paintings for popular consumption often incorporate ideological contradictions:

Postcolonial nationalist iconography ... has sought to articulate in a visual idiom the developmental, modernising and nation-building agenda of the post-colonial state. Typically, it has done so ... through the attempted (visual) reconciliation of fundamental contradictions in the state's developmental agenda by bringing opposites into a productive and symbiotic conjunction. There is thus no contradiction of choice ... between Indian tradition and westernised modernity: all are in productive service to the nation-state. $^{23}$

In an earlier article, Uberoi describes how bāzār art-both sacred and profane-participated in the commodification of images of women while simultaneously "tropising $[$ sic $]$ the feminine." ${ }^{24}$ By this she means turning images of women into tropes symbolizing certain national ideals even while offering them for consumption by the male gaze. The Shama cover pages certainly can be viewed through this lens, although rather than doing the work of the nation-state per se, the cover paintings become part of the imaginary of the evolving Urdu cosmopolis.

The work of Kajri Jain is also relevant to the Shama cover paintings. In particular, she discusses how popular images of women mediate between pornography and patriarchy, and how the viewer can experience the scopic pleasure of the female body even while condemning the moral slippage implied by the

23 Uberoi, "Chicks, Kids and Couples," 198.

24 Uberoi, "Feminine Identity and National Ethos," WS42. 
revealed female form. ${ }^{25}$ Yousuf Saeed likewise points to the contradictions found in popular art catering to the Urdu and Muslim public(s). He describes how many such images combine the seeming opposites of domesticity and liberation, showing women who may be interpreted as modern in their dress and bold expressions even while inhabiting domestic or otherwise "safe" spaces. ${ }^{26}$ All three scholars-Uberoi, Jain, and Saeed-remark on the "failure" of the romantic trope, i.e. the almost complete absence of depictions of couples, married or otherwise.

I will look at several covers from the 1950s and 196os, when Shama was at its peak circulation. There were two in-house illustrators who dominated these decades: Siddiqui (full name unknown) and Inderjeet, who was also known under his poetic pen name, "Imroz." I have not been able to discover much about Siddiqui, but I was able to interview Inderjeet, who was writer Amrita Pritam's longtime companion. ${ }^{27}$ Siddiqui's work is painterly, generally featuring lifelike portraits and domestic settings, while Inderjeet's are essentially sketches, often using a palette restricted to two or three colors.

Both painters almost always portray the female subject alone, although sometimes she is with a female companion. My analysis centers on the gaze: both the portrayed gaze of the subject herself and the gaze of the implied viewer. ${ }^{28}$ The power of the gaze, and particularly the meeting of glances, is a ubiquitous trope in South Asian literature and culture, perhaps originating in the Hindu concept of darshan (divine vision). ${ }^{29}$ With the literary conflation of divine and erotic love, the power of darshan, which is always bi-directional, may be applied to the gaze as exchanged between lover and beloved. In the Shama cover paintings, the female subject's gaze may be either directed at the viewer or looking elsewhere thoughtfully, but in the vast majority of cover paintings the subject's gaze is oblique-what in Urdu-Hindi we might call a tirchhin nazar (oblique glance). If she is portrayed frontally, her gaze looks off to one side; if she is drawn in profile, she is often glancing out of the page through the corners of her eyes.

25 Jain, Gods in the Bazaar, 304.

26 Saeed, "Ishtihar Tasveeren," 5.

27 Portions of this interview are in "Afroz Taj in Conversation with Inderjeet 'Imroz." When I met him in 2011, Inderjeet was in his mid-gos. He had worked for Shama from the late 1950s until the 1970s.

28 What we might call "gazeology" is a relatively old field of study, but it was first delineated as a branch of feminism and post-modern cultural studies in Mulvey, "Visual Pleasure and Narrative Cinema." Mulvey's theoretical framework has been extensively critiqued and expanded by subsequent research. See, for example, James D. Bloom, Reading the Male Gaze in Literature and Culture.

29 Darshan in its original sense connotes visual contact with the divine: see Eck, Darśan. 
The tirchhinazar trope has an important effect on the Shama cover paintings because the oblique glance is semiotically rich, and essentially different from the direct glance. The tirchhi nazar is associated with flirtation, love, longing, and other affective states. A person portrayed employing an oblique glance has a story, a personality. The direct glance, on the other hand, may be frank and even confrontational, but also (as in many traditional portraits) emotionally static. The Shama covers rarely employ the direct gaze, but when they do, the effect is of surprising boldness.

In the larger context of South Asian culture, these cover paintings challenge a number of social restrictions and taboos. According to tradition, womenespecially young women-were not supposed to be subject to the male gaze at all. Women were to be protected by a complicated system of pardah (lit. "curtain" but referring to seclusion) and veiling, which was not by any means exclusive to Islamic culture in South Asia. I do not have space in this article to discuss the history of women's covering and seclusion, but suffice it to say that for Shama's Urdu-speaking audiences, the frank and even bold portrayals of young women were certainly provocative, even well into the postIndependence era. In the Islamic context specifically, people are enjoined to lower the gaze when confronted by someone of the opposite sex. Shama's cover women generally do not "lower the gaze" at all, but rather deploy their gaze for expressive purposes. The trope of the gaze as an arrow that pierces the heart of its object is ubiquitous in the Urdu poetic corpus. Although we know the cover subjects have been painted by a male artist, they still appear to have agency and even what might be called scopic power, the power to return the viewer's gaze.

No matter where the gaze is directed, the Shama covers largely represent either of two affective modes: I will refer to these as "interactive" and "pensive." The direction of the subject's gaze is the primary factor that defines which mode may be read into each painting. When the eyes in a presented image gaze to the left or right, we tend to understand her as thinking about something outside the spatial or temporal frame of the picture. Such an image evokes the pensive mode: the subject is either missing someone from her past or hoping to see someone from her present or near future. ${ }^{30}$ In the interactive mode, the subject seems to be conscious of the viewer's gaze and responding

30 There is a great deal of psychological, sociological, and art-historical research on gaze direction with respect to affect and cognition, but approaches that attempt to map specific gaze directions onto specific emotions or cognitive processes (e.g., NLP) have been largely dismissed as pseudoscience. See Witkowski, "Thirty-Five Years of Research on Neuro-Linguistic Programming." 
to it. She may be looking directly at the viewer, or at someone in the viewer's imagined space. In both modes, the configuration of the painted subject's and the viewer's gaze opens space for fantasy. The viewer is encouraged to imagine a relationship with the subject of the painting: she is thinking of me, waiting for me, interested in me.

Below are two examples of covers by Inderjeet from the late 1950s-note his distinctive signature in the lower right corners. The women are dressed fashionably but not ostentatiously. They are certainly attractive, and their flimsy dupattās (scarves) accent rather than hide their figures. Inderjeet's visual wit is apparent in the right-hand image (Figure 5): the blue-on-black leaf/feather pattern in the background is echoed in the blue-on-white design on the woman's garment, and in her blue earrings. The woman on the left (Figure 4), although presented frontally, gazes to her left (the reader's right), exemplifying the "waiting" motif that is often encountered in the pensive mode. The woman on the right, although presented in profile, is actually looking at us, demonstrating that this trope of the tirchhi nazar (oblique gaze) is similarly prevalent in the interactive mode. The oblique gaze often connotes coyness, and even flirtation.

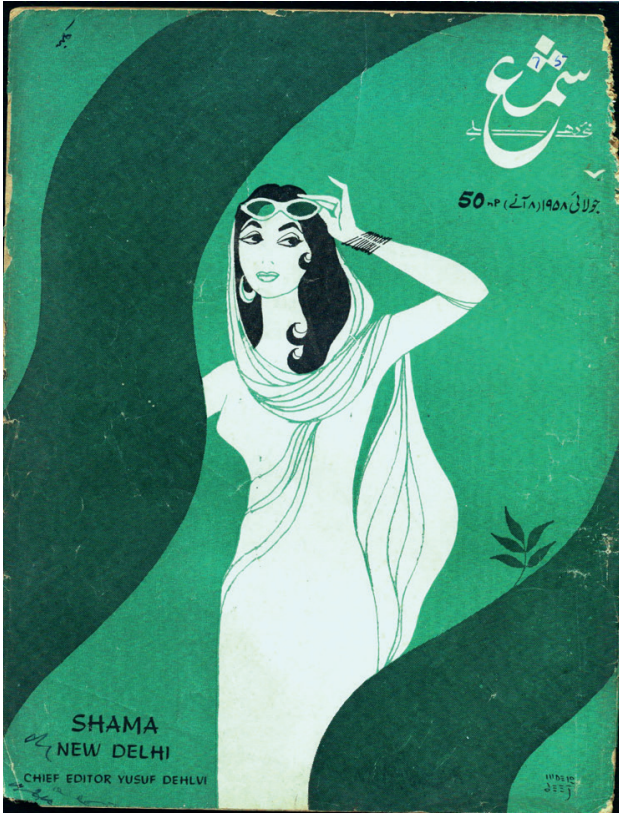

FIGURE 4 Shama cover painting by Inderjeet, July 1958. Reproduced with permission of Mohsin Dehlvi

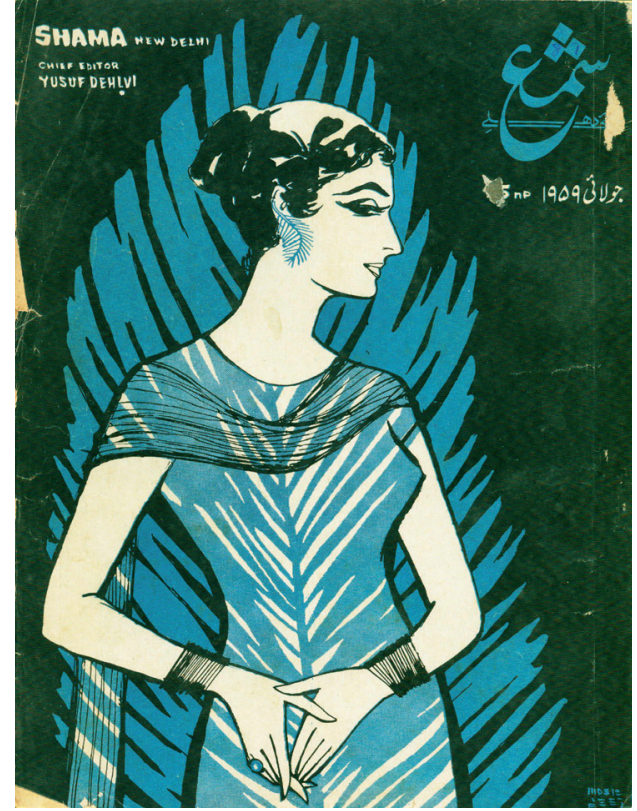

FIGURE 5 Shama cover painting by Inderjeet, July, 1959. Reproduced with permission of Mohsin Dehlvi 


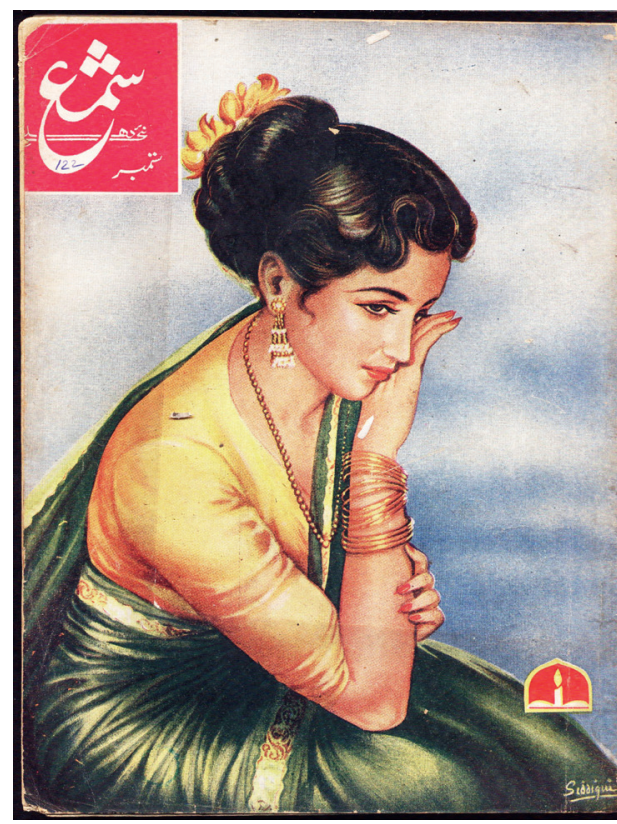

FIGURE 6 Shama cover painting by Siddiqui, early 196os. Reproduced with permission of Mohsin Dehlvi

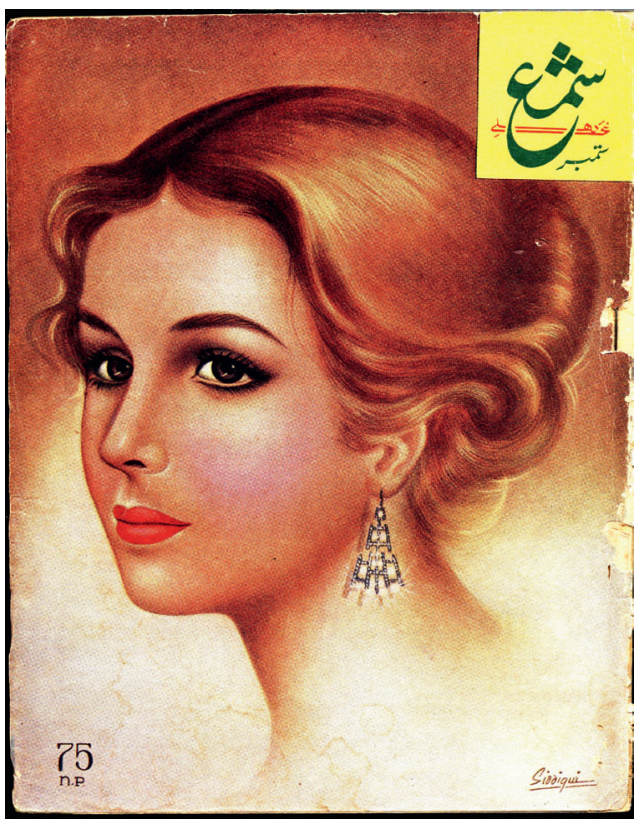

FIGURE 7 Shama cover painting by Siddiqui, early 196os. Reproduced with permission of Mohsin Dehlvi

Clearly these are women with stories. But what can these stories be? Are they married? All of the cover women are wearing bangles and a few even have bindīs (decorative cosmetic marks on the forehead). Bangles and bindīs were traditionally symbols of Hindu matrimony, but by the 1950s this semiotic association was weakening and both could be otherwise interpreted as fashion accessories. These symbols, when taken within the context of the Urdu cosmopolis, might be considered markers of secular modernity in the sense that they make ambiguous - rather than reveal—the religion and marital status of the woman portrayed. The viewer/reader is thus left to fantasize.

Above are two paintings by Siddiqui from the early 196os. The painting on the left is striking for its sartorial conservativism, while the one on the right is almost shocking in its implied low neckline. The woman in the sari is in pensive mode, but clearly displaying her bangles to the viewer like a new bride. She is waiting for someone special, but we are not the object of her longing. The woman on the right is also in pensive mode, but somewhat disconcertingly looks almost — but not quite - at us, as if she is looking at someone over our left shoulder. She is blond, with pink blush on her cheeks, reflecting a different 


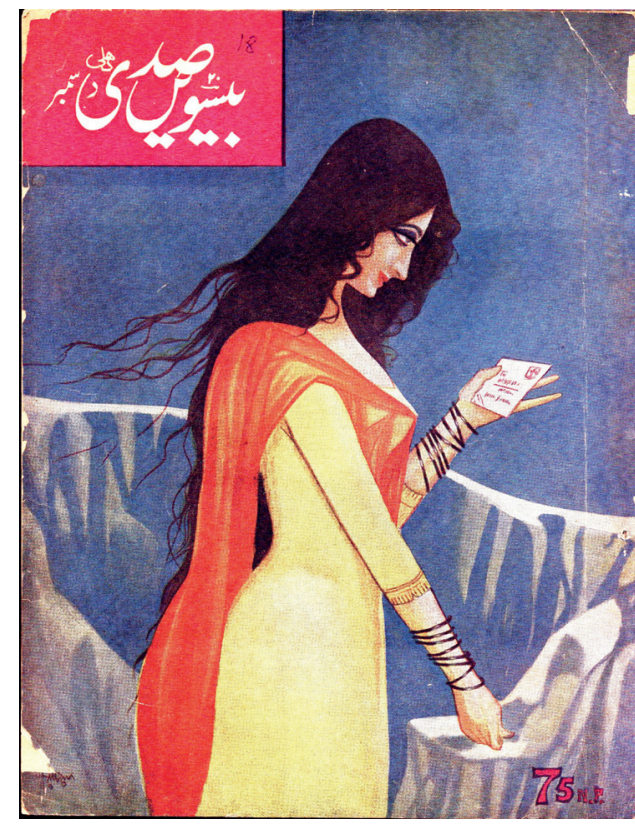

FIGURE 8 Bīsvīñ Șadī cover painting, September, year unknown. Reproduced with permission of Suparna Chadda

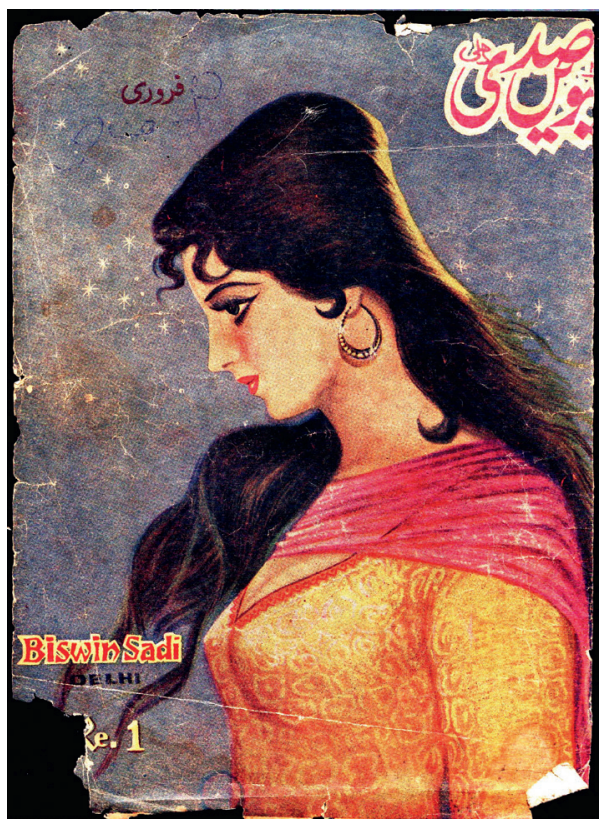

FIGURE 9 Bīsvīñ Șadī cover painting, February, year unknown. Reproduced with permission of Suparna Chadda

racial notion of beauty. If we read her as cosmopolitan, then we may be not quite as shocked by the absence of any visible upper garment.

Shama was by no means the first or only magazine to use paintings or photos of women on its cover. Gail Minault has studied women's magazines in Urdu going back into the nineteenth century, and gives an example of a $193^{2}$ cover drawing from Tahīib un-Nisvān (Women's Culture) showing a lovely young woman reading the selfsame journal. ${ }^{31}$ This practice continued in many other magazines including Bīsvīn Șadī, Shama's main competitor in the Urdu literary monthly market. ${ }^{32}$ Let us compare the covers of Shama to contemporaneous covers of Bīsvīn Șadī (Figures 8, 9). These covers too featured paintings of women, with subtle but significant differences.

These covers are quite typical of Bīsvīn Șadī. The women, presented in profile, are just as nubile and fashionable as those on Shama's covers. However, the

31 Minault, Secluded Scholars, 117.

32 Bīsvīn Ṣad̄̄ was published by Ḳhvushtar Girāmī (Rām Rakhā Mal Chaḍ̣ā) from 1937 until 1977. These cover illustrations are unsigned and the cover artist is not credited in the magazine. 
fundamental difference is in the gaze of the women themselves. In Figure 8, the women's gaze is focused on a letter, and she smiles ambiguously, anticipating either opening the letter or sending it. The gaze of the woman in Figure 9 is also focused, although we cannot see the object of her attention which is out of the frame. These two images do not fall into either of the categories I created for Shama. The women are neither pensive nor interactive; they are simply attentive, looking directly at something that engages their attention. Thus the tirchhi nazar is absent, as are the connotations of flirtation and innuendo.

The tone of Shama's cover paintings changed with time. In the 1940s and early 1950s, there were few bold glances: the pensive mode prevailed, as did traditional dress. By the late 195os and 196os, the women were more likely to be wearing modern fashions, sporting modern hairstyles, and looking out of the frame toward-if not directly at - the viewer. For a short period in the late 1970s, the covers featured scenes from newly released films, and then they changed again in the 1980s to show color photographs of actresses. Some of these were stills from films while others were publicity photos. In either case, the actresses were often looking directly at the viewer in full frontal poses. But in the implied realism of a photo, there is no room for the fantasy evoked by

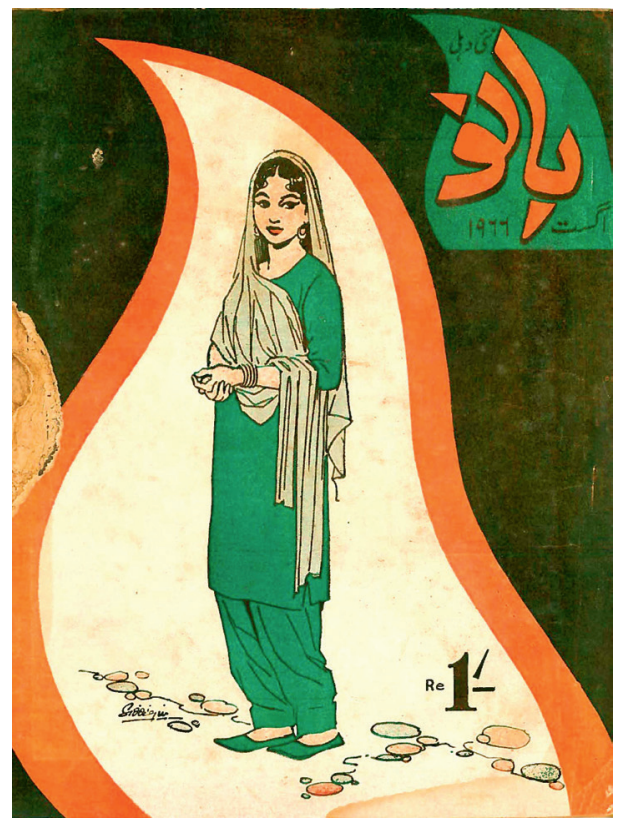

FIGURE 10 Bāno cover painting by Siddiqui, August 1966. Reproduced with permission of Mohsin Dehlvi

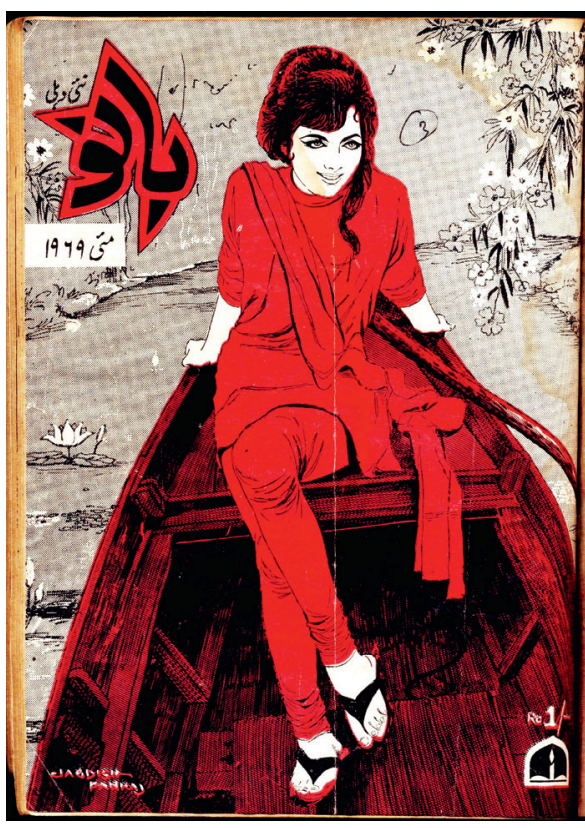

FIGURE 11 Bāno cover painting by Jagdish Pankaj, May 1969. Reproduced with permission of Mohsin Dehlvi 
the paintings of Siddiqui and Inderjeet. These actresses can be seen by anyone on the silver screen, thus lacking the intimacy experienced by the single viewer holding the magazine whose cover image appears-sometimes- to be gazing back.

The covers of Shama's sister publication, Bāno (Figures 10, 11), were largelybut not completely-innocent of sexual innuendo, although they too contained exclusively images of women. Bāno was edited by Younus's wife, Zeenat Kausar, and then by their daughter, Sadia Dehlvi. The act of appointing women of the family as the chief editors of Bäno was a shrewd marketing strategy, allowing the Dehlvi family to perform both piety and progressivism.

Bāno was explicitly a women's magazine, and the women depicted on the covers were proffered-ostensibly - for the female gaze: women to be emulated in terms of beauty, fashion, or, importantly, modernity. In Figures 10 and 11 (above), we see that in the space of a few years between 1966 and 1969, the penchant for painting "traditional" dress and demeanor had changed to be somewhat more daring: in Figure 11, a young woman, significantly without bangles, sits in a small boat looking up at someone standing to the viewer's right, which would place the object of her gaze on the bank, perhaps.

It was because of its ambiguously seductive cover paintings that Shama was considered to be mildly pornographic. Clearly targeted to the male gaze, the cover paintings emphasized physical beauty, voluptuous figures, fashionable clothes, and implied flirtation. Perhaps this too was a marketing ploy based on the notion that men would be attracted by the covers alone to purchase the magazine from the newsstand, although subscriptions accounted for the vast majority of sales. In any case, the covers might be called false advertising, since they give little indication of the filmi--ilmi content of the magazine itself but rather seem suggestive of sexual trysts and illicit affairs. Although Shama occasionally published short stories that contained relatively frank discussions of female sexuality, the cover paintings were not illustrations of a particular story found inside the issue. The paintings may merely have been intended to allude to the potential for risqué content within.

\section{Under the Covers}

If Shama's outward packaging courted the male gaze in its most basic form, the magazine's contents tell a very different story. The content does not seem to be significantly male-oriented at all, but rather participates in the notion of progressive Urdu modernity: it assumes a cosmopolitan readership that is not specifically gendered, classed, or belonging to a particular religious community. 
Shama published stories by established women writers like 'Ișmat Chugihtāì Ṣāliḥah ‘ābid Ḥusain, and Vājidah Tabassum, but also works solicited from its readership, including talented amateurs like my older sister, Zeb Naqvi. The prevalence of women's literary voices helped further to attract female readership by counterbalancing the objectification and commodification projected by its female images. Shama was thus one of the first Urdu journals to feature fiction that challenged gender norms and broke new ground in writing about women's sexuality. Although 'Ișmat Chug̉htāì and Vājidah Tabassum wrote about matters like sex outside of marriage, their stories were not salacious. Indeed, Shama's literary content was of a consistently high standard. ${ }^{33}$

To get a better idea about Shama's actual content, let us look at a particular example, the March 1959 issue. True to form, the cover page (Figure 12) consists of a young woman standing in a doorway, smiling shyly, looking intently at the reader. One hand holds a rose while the other is slightly extended to accentuate the fall of her diaphanous dupatt $t \bar{a}$ (scarf). According to Inderjeet, the artists had specific instructions about how to create these cover paintings to combine domesticity with flirtation. This particular cover shows a girl contained within her boundaries but looking out at the observer. The wall or fence that contains her is ironically an openwork grille that hides nothing. According to theories of the gaze, the woman portrayed provides a variety of possible overlapping scopic pleasures, some libidinal, and some emulatory. This smiling maiden is a kind of idealized reflection: she appears to be like the observer-perhaps a sister or friend - but but with the merest hint of naughtiness in the gaze.

The cover page also includes the distinctive Shama logo which reads "Sham" Na'ı Dihlī" along with the text in Roman script "Shama / New Delhi / Chief Editor Yusuf Dehlvi," the issue month and year in Nasta līq script, and the newsstand price of fifty new paise. ${ }^{34}$ The use of "New Delhi" is interesting because Shama's main office and printing presses were actually in Old Delhi, while only the family's mansion residence was technically in New Delhi. The mansion itself became a character in the magazine; many film stars stayed as house guests with the Dehlvi family on their visits to the capital, and photos of celebrities with Yusuf and his children at home were featured in every issue. The

33 Many of the authors published in Shama were either already famous or would use Shama as a steppingstone to subsequent renown. The roster included 'Ișmat Chuğhtāì, Firāq Gorakhpūrī, Prakāsh Panḍit, Shakīl Badāyūnī, Gulzār, Rām Lāl, Rājindar Singh Bedī, Qamar Jalālābādī, Shamīm Jaipūrī, Shaukat Thānavī, Jigar Murādābādī, Ḳhvājah Aḥmad 'Abbās, Vājidah Tabassum, Naresh Kumār Shād, Sirāj Anvar, Krishan Chandar, Qatīl Shifā̄ī, Sudarshan Fākhir, etc.

34 India decimalized its coinage on April 1, 1957: one new paisā was equal to one hundredth of a rupee. 


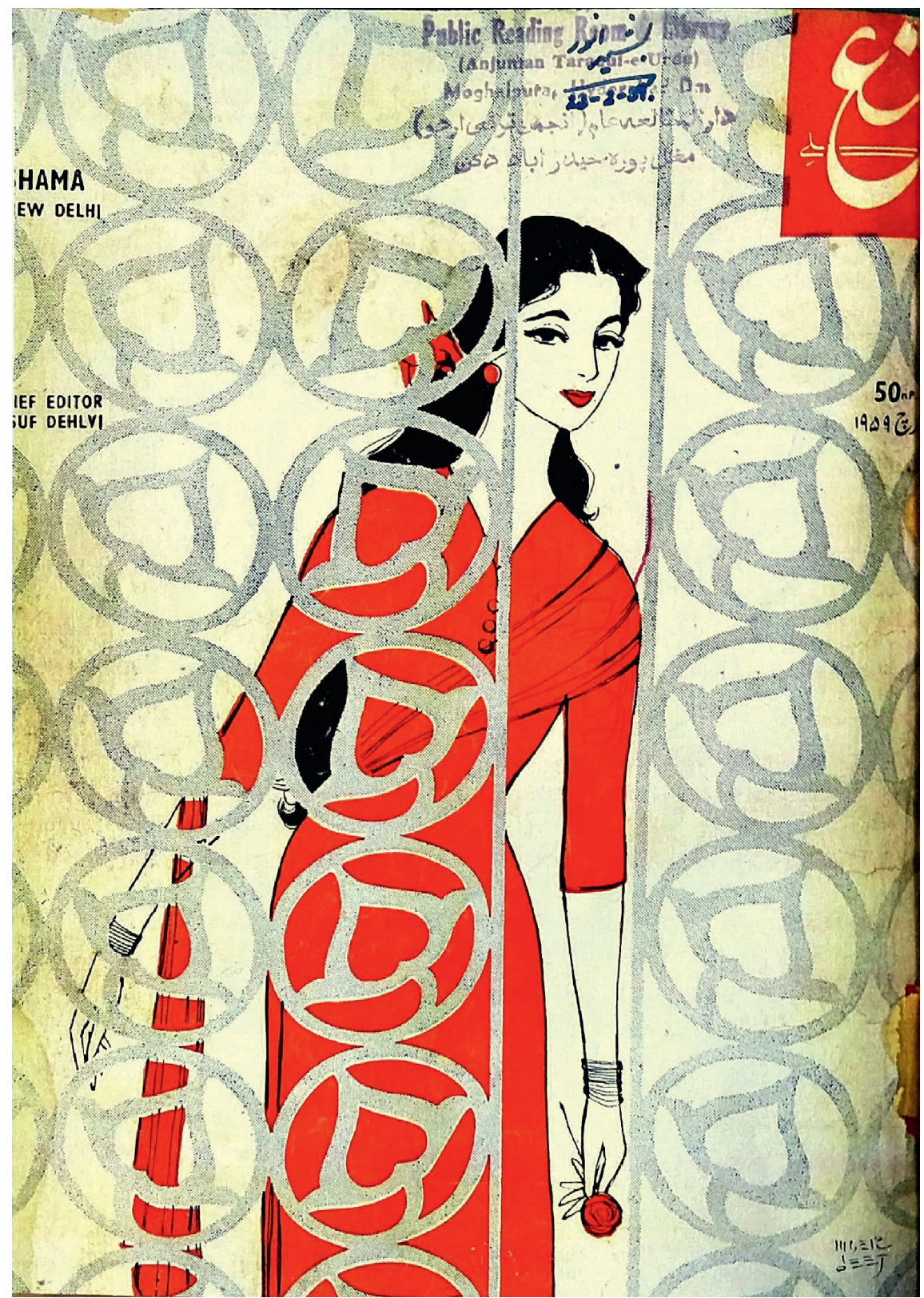

FIGURE 12 Shama cover painting by Inderjeet, March 1959. Reproduced with permission of Mohsin Dehlvi 
readers were invited — virtually — into the Dehlvi home. This too was a marketing strategy. The Dehlvi family was — as their name affirmed — based in Delhi, the political capital, but their livelihood was based on the industry centered largely on Bombay; thus the photos of stars at the Dehlvi home forged an ongoing link between Delhi and Mumbai. In the Nehruvian era of modernization and nation-building, which was very much directed from the center, Shama visually represented the negotiation between popular culture and progress.

The rest of this - and every-issue consists of an interplay of image and text. These juxtapositions often emphasize the links between film celebrity, Urdu literature, middle-class values, and aspirational modernity. At many junctures in each issue, Shama foregrounds the notion of an Urdu public that is a community of readers who interact and correspond with the magazine's editors to discuss a variety of issues of public concern. Shama generally shies away from the overtly political, but does engage readers with discussions of culture, literature, language, and, of course, film.

Each issue of Shama is divided into two sections. The filmi section comes first, followed by the literary section. The first four or five pages of each issue are taken up by full-page photos of actresses (and occasionally actors). Beneath every photo is a couplet of Urdu poetry that converses with the photo, alluding to the subject's beauty or emotional state, or to the assumed reaction of the viewer. In the March 1959 issue, on the verso of the cover, we see actress Nargis in a still from the 1958 film Läjvantī (Modesty). ${ }^{35}$ The reading public would have been fully aware that Nargis was Muslim, but in the photo she is wearing a bindī and has her head covered, evoking her role as a Hindu pujārin (female worshipper) in the 1950 film Jogan (Female Ascetic). On the facing page, the actress Nutan poses with a large flower. Both Nargis and Nutan are portrayed in the pensive mode, looking not quite at the viewer. Nargis's gaze is very slightly lowered, conveying modesty, while Nutan's gaze is directed just to the left of the viewer's line of sight, connoting anticipation. On the next verso page (page 4), we meet actress Nishi from the $195^{8}$ film Milan (Meeting). Her hair is down, and she is looking seductively over her shoulder directly at the viewer. This couplet appears below (in my translation):

35 Läjvantī won the National Award for Best Feature Film in Hindi in 1959. It was also India's entry in the 1959 Cannes Film Festival and was nominated for the Palme d'Or. 


\section{Mahabbat kā tum se asar kyā kahūñ \\ Nazar mil ga’̄ dil dharakne laga $\bar{a}^{36}$}

What can I say about the effect of your love?

Our eyes met and my heart started to pound

On the facing page is a photo of actress Meena Kumari, the "Tragedy Queen," looking almost accusingly into the camera, followed on the verso by a photo of Ashok Kumar (a male actor), with gaze lowered and a serious if inscrutable expression.

After the series of five star photos, the magazine gets down to business. The next page gives us the editor's message under the heading "Rāz o Niyāz" (Lover's Secrets), but without a byline. Like the cover paintings, the title of this section seems to promise something risqué within, but in the March 1959 issue the editor's message concerns a rise in the price of Shama due to inflationary increases in production costs. On this same page is the editorial board is listed: chief editor (mudìr-e a'lā ) Yusuf Dehlvi; editor (mudīr) Younus Dehlvi; illustration editor (mudīr-e tașāvir) Idrees Dehlvi. ${ }^{37}$ Inderjeet is credited as the illustrator (husn-kār). The following pages contain advertisements for soon-to-be released films including Sohrab Modi's film Minister, for which Shama is listed as the Uttar Pradesh and Delhi distributor (p.8), and Milan, "a Shama presentation" (p.12). There is also a three-page promotional feature on Mugihal-e A'zam (The Great Mughal), a film that had been decades in the making and would finally be released in August 196o (p.9). These ads featured collages of publicity stills from the films. Ads for additional films are scattered throughout the magazine.

On the next four pages (13-16), under the heading "Pas-Manzar" (Behind the Scenes), there are many photos of actors and actresses at their homes, at private functions, or on film sets. Each photo is accompanied by a caption explaining and commenting on the photo. Although the captions are often satirical, they are never vicious or critical of the stars. Other filmi features in this issue include "Tinke" (Straws) and "Idhar Udhar" (Here and There). "Tinke" contains tidbits about celebrities' marriages, divorces, and weight gain but avoids naming names; the reader is implicitly invited to guess who the target is. The title, "Tinke," derives from a popular anecdote about a $q \bar{a} z \bar{l}$ (legal scholar) who captured a thief by gathering the suspects together and announcing that

$36 \quad$ Kullìyāt-e Akbar Allāhāāàdī, vol. 1, 17 .

37 The youngest son, Ilyas Dehlvi, is not listed here, presumably because he was not yet of age in 1959 . 
the thief would be the one with a telltale straw in his beard. The suspect who immediately started checking his beard inadvertently revealed himself as the thief. Thus the unnamed person targeted in each "Tinke" blurb would be outed if they complained publicly. "Idhar Udhar" alludes to an Urdu idiom, "idhar udhar kī bäteñ," which literally means "things [said] here [and] there" but might be loosely translates to "gossip." This section contains news about stars and forthcoming films. Also in this filmi domain is a section listing the birthdays of various movie stars. Shama invites readers to send these artists birthday cards, and suggests they mention that they found out about the birth dates from Shama so that the actors will reply. This is an example of how Shama strove to be interactive, to involve its readers in the film world.

In the midst of the film $\bar{\imath}$ section, we find a two-page feature celebrating the double marriages of Yusuf's sons Ilyas Dehlvi and Idrees Dehlvi. At the top of the first page is a triptych of photos, the iconic Dehlvi Mansion flanked by pictures of the two grooms. Idrees is in a Western suit while Ilyas is in cap and shervānī (long buttoned coat). Below a paragraph of text and the headline "Jashn-e Masarrat" (Happy Celebration) are two photos: one of the two brides sitting demurely with downcast eyes, and one of proud father Yusuf with a foreign delegation. On the next page are photos of celebrity guests. Publishing personal photographs of the Dehlvi family served both to reinforce their celebrity status and to include readers in the extended Shama family. It is this Shama family, portrayed as predominantly Muslim and Urdu-reading but also progressive and cosmopolitan, that forms one visual manifestation of the midtwentieth-century Urdu public.

After the filmi sections, the first literary selections begin on page 29. These include a ghazal by Firāq Gorakhpūrī with 27 couplets (Figure 13), followed by a story by the prominent writer Krishan Chandar, "Khațte Anār Mìțhe Anār" (Sour Pomegranates, Sweet Pomegranates). Both the ghazal and story are accompanied by sketches by Inderjeet. The story illustration merely shows a pomegranate tree, but how does one illustrate a ghazal? Inderjeet's sketches for ghazals almost always consist of idealized women's faces. This association between Urdu poetry and feminine beauty not only reinscribes similar juxtapositions throughout the magazine, but also visualizes the connotation of the word "ghazal" ( $\mathrm{g} h a z a l)$ itself, which means "speaking in an amatory or enticing manner." 38 Although a single ghazal may include many unrelated ideas, a common theme is the pain of unrequited love, and Inderjeet's women often

38 As per John T. Platts's Dictionary of Urdu, Classical Hindi, and English (London: W. H. Allen \& Co., 1884), which may be found online at https://dsal.uchicago.edu/dictionaries/platts/. The ghazal entry is on page 771 . 


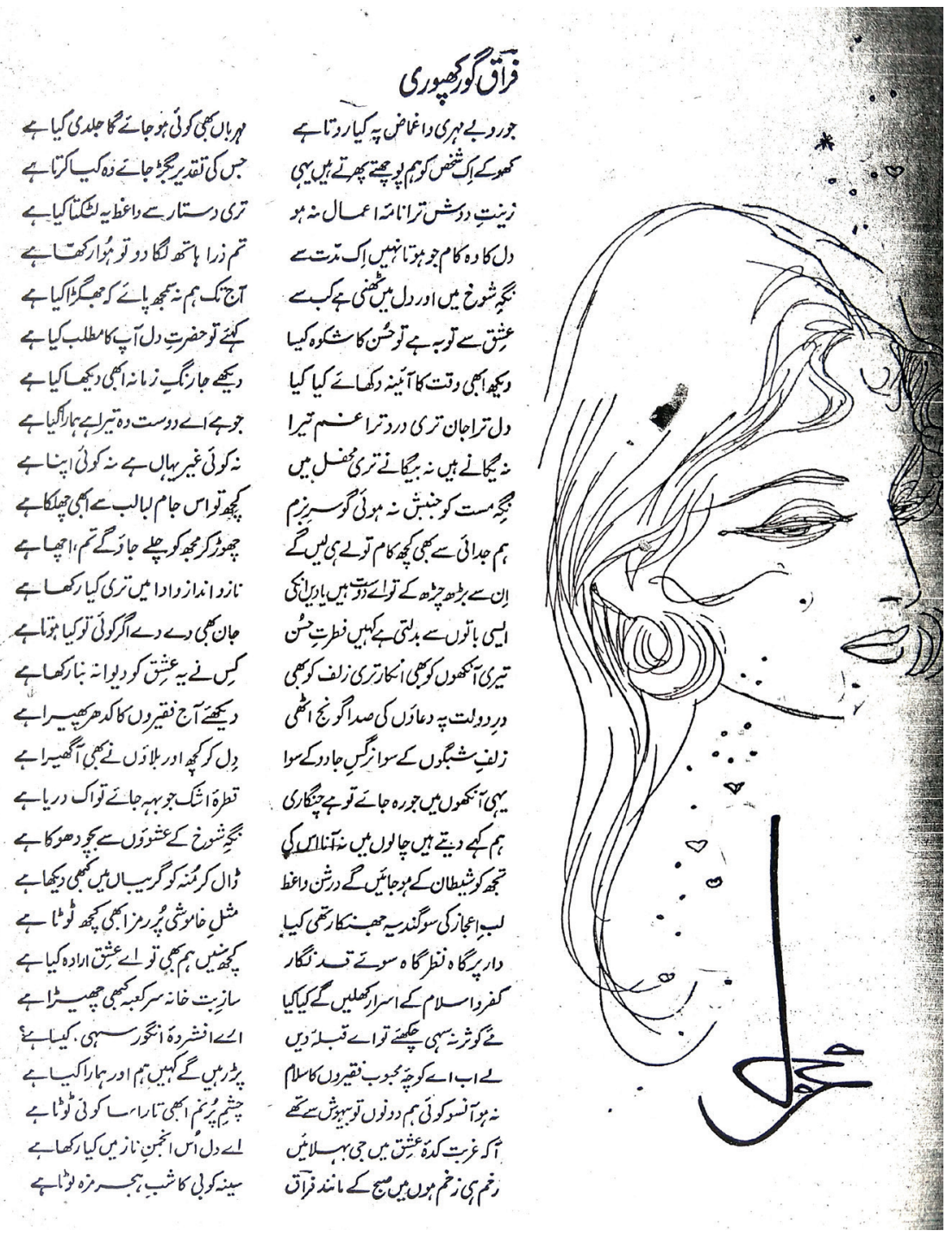

FIGURE 13 Ghazal by Firāq Gorakhpūrī with illustration by Inderjeet, Shama, March 1959, page 29

seem melancholy or pensive. ${ }^{39}$ This raises the question of subjectivity: Does the woman depicted represent the artist's fantasy, the poet's muse, or

39 Indeed, it seems to me that Inderjeet always drew the same woman: his partner Amrita Pritam. 
possibly the person from whose experiences the ghazal emanates, that is, the poet's persona? ${ }^{40}$

Interspersed with the literary content and advertisements are more photographs of actresses (or an occasional actor) accompanied by couplets of poetry. For example, in the middle of Krishan Chandar's story we come across a photo of actress Anītā Gūhā with the following mișra' (line): "Shabāb āyā kisì but par fidā hone kā vaqt āyā" (An idol has been endowed with youth, the time to be sacrificed has come) ${ }^{41}$ In the photo, Anītā Gūhā's garments are off the shoulder, and her gaze is fixed on the reader. Her persona in this photo would have been startling for readers, since Gūhā was chiefly known for playing Sītā and other female protagonists in films based on Hindu mythology. This is an example of how Shama's Urdu context resists Hindu nationalist "tropising" (to use Patricia Uberoi's coinage), not by replacing it with Islamic tropising but rather by infusing it with erotic innuendo, thus both modernizing and commodifying the female image.

The 'ilmi section includes several more selections by lesser known writers and poets. On one page we find ghazals by two different women: Salmā, BA, and Svaran Latā "Nāzish," MA. The inclusion of their educational qualifications indicates that these are most likely amateur poets who, like my older sister, had submitted their works for publication in Shama. By their names, we can assume that one is Hindu and one is Muslim —an important marker of Shama's inclusiveness and a comment on Shama's readership.

Elsewhere the issue we encounter several features specifically focusing on the Shama community, that is, the extended readership. The first of these is "Bazm-e Sham" (The Shama Gathering), in which readers submit questions and the editors respond. The responses are sometimes tongue-in-cheek but at other times exchanges of information. Nearing the end of the issue we find "Kasauți” (Touchstone), which contains criticism of newly released films, and "Jhalkiyāñn" (Glimpses) with brief notes on films in progress. Finally, there is a section for letters from readers called "Bāzgasht" (Echoes/Feedback). In this section, readers share their opinions, often addressing cultural issues: for example, the infiltration of rock and roll into Hindi film songs.

At the very end of each issue we find one of Shama's most famous features, the participatory "Adabī Mu'ammah" (Literary Crossword Puzzle), which in March 1959 bore a prize of 15,000 rupees, over 100,000 rupees in today's

\footnotetext{
40 An exploration of the visual interpretation of ghazal and the fascinating interplay of gendered roles and personas found therein is beyond the scope of this paper.

41 This is the first line of a ghazal by Harī Chand Aḳtar, which may be found in his Kufro Imān, 34 .
} 

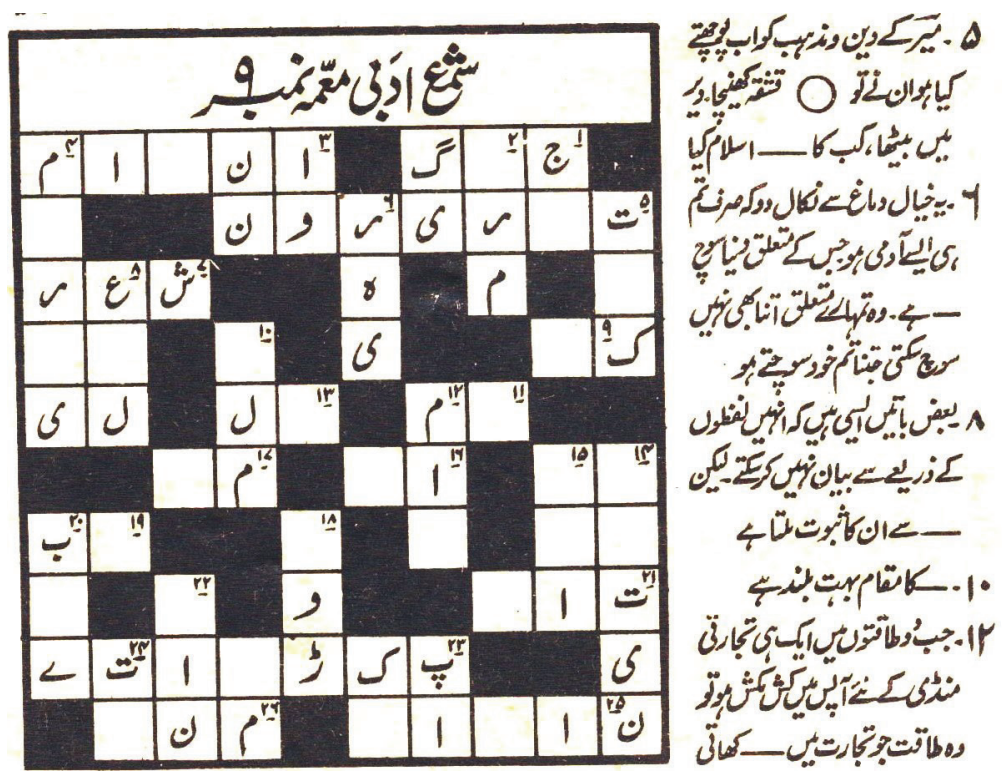

FIGURE 14 An example of the Sham'Adabì Mu'ammah crossword puzzle from September 1963

currency (Figure 14). Readers who wished to enter the mu'ammah contest were required to enclose a small entry fee and token coupon with their submission (Figure 15). Legend has it that the day of each contest deadline rupees would arrive in enormous gunny sacks, and the company had to keep a special contingent of bookkeepers on retainer just to count the incoming cash. ${ }^{42}$ Some fans would buy hundreds of issues to obtain the coupons and others reportedly made a business of submitting entries for other people. Readers who filled in the mu'ammah felt that they had demonstrated — at least to themselvestheir command of Urdu literary cultural capital. Meanwhile, people on the highbrow side of the spectrum who might not have otherwise read Shama were captivated by the puzzle and its literary pretensions. In any case, the mu'ammah became the lynchpin of Shama's market growth.

\section{Advertising and Readership}

The advertisements in Shama provide evidence that women constituted a significant segment of Shama's readership. While these ads promote a large range

42 When I speak of "legend" in this article, I am referring to stories told to me by multiple sources, including stories I heard growing up in India and in my recent interviews. 


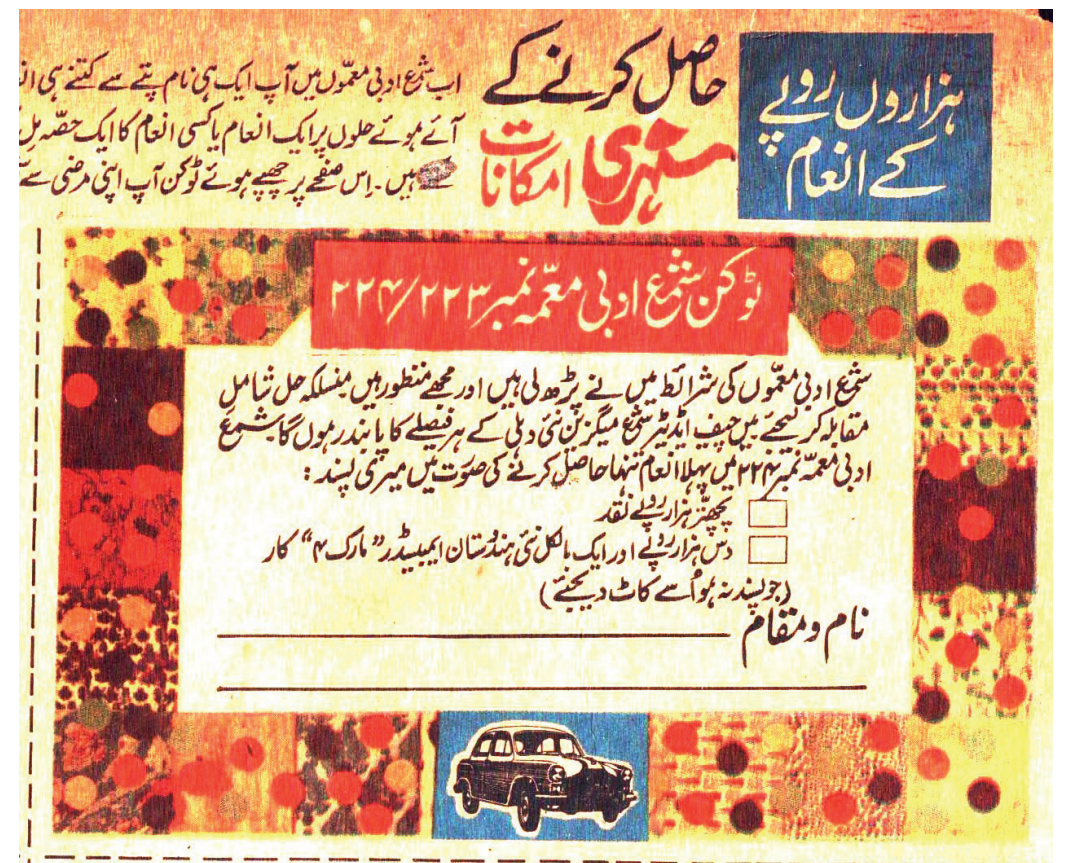

FIGURE 15 A "token" (coupon) that was to be returned with the solved crossword and a contest fee

of products, the majority of them seem to be marketed to women (Figures 16 and 17). Most of these ads are illustrated with line-drawing images of "modern" women, revealingly dressed according to the intimate settings of the bath or toilet. The advertisements in the March 1959 issue promote women-oriented products including a selection of detergents, soaps, hair oils, depilatories, beauty creams, powders, shampoos and a fish spice mixture whose ad includes a recipe and a photo of a very Western-looking fish casserole. The names of products like Charmis Snow Cream and Hazeline Snow imply that they lighten skin tone. ${ }^{43}$ Products whose ads contain images only of men, or no images at all, include pain killers, toothpaste, vitamins, tea, airlines (the British Overseas Airways Corporation), industrial abrasives, and radios. Only three ads portray the ideal nuclear family (i.e., a mother, father, boy, and girl). In one such ad, all applaud Protext All Purpose toilet powder; in the second, a family approves

43 There is a vast range of literature on both nudity in advertising and cross-cultural obsessions with skin tone. See, for example: Kang, "The Portrayal of Women's Images"; Paek and Nelson, "Cross-Cultural Differences in Sexual Advertising"; Cardoza and Parameswaran, "Melanin on the Margins"; Linhart and Dianoux, "The Effectiveness of Female Nudity in Advertising"; Huang and Lowry, "An Analysis of Nudity in Chinese Magazine Advertising"; and Choi et al., "Do Feminists Still Respond Negatively to Female Nudity in Advertising?" 


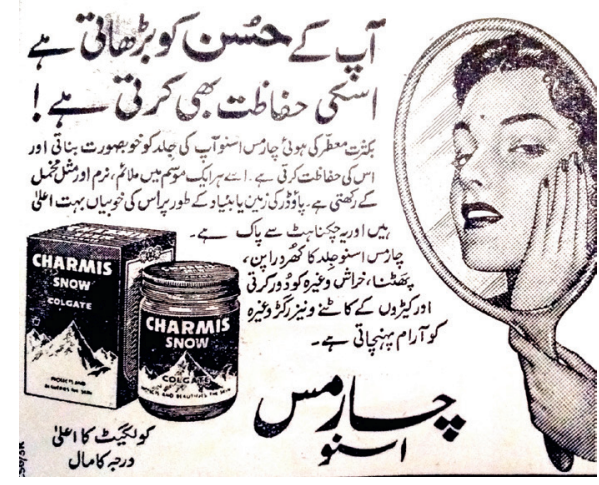

FIGURE 16 Advertisement from Shama for Charmis Snow skin cream, March 1959 issue, p.48
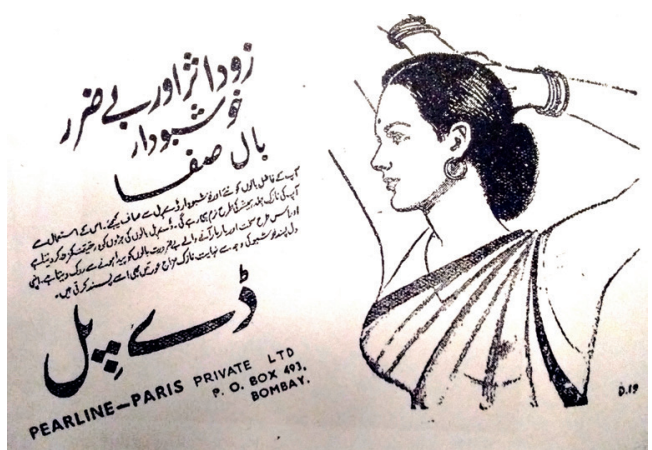

FIGURE 17 Advertisement from Shama for Pearline De Pil depilatory, March 1959 issue, p.7o

of Parry's toffees; and in the third, the family gathers around a National Echo radio. Many products are from foreign companies like Colgate, Palmolive, and Lakmé, while others are Indian brands that boast of Ayurvedic or Unani ${ }^{44}$ ingredients like neem (Azadirachta indica, a tree native to South Asia that is believed to possess many medical properties).

As explored by Yousuf Saeed, advertisements in Urdu journals like Shama emphasized a modern consumerism that promised women a degree of empowerment and liberation even while reinforcing their domesticity. ${ }^{45}$ The household and beauty products promoted in Shama exemplify the mid-twentieth-century surge in brand consumerism, while others, like radios, fish casseroles, and airlines point toward a cosmopolitan modernity. Particularly relevant to the Shama case is Saeed's observation that there was no contradiction in juxtaposing ads for Western products with ads for Unani and other local products.

Clearly, the publishers knew that women constituted a large share of Shama's readership. But then why do so many of my interlocutors talk about the stigma applied to women reading Shama? From my interviews with former Shama employees and managers, I get the sense that the aura of the risqué was cultivated chiefly as a marketing strategy. By fostering Shama's reputation as not suitable for respectable women, the management ensured that women would read it, and that men would want to read it also- - both to find out what

44 Unani refers to the complementary medical system traditionally associated with South Asian Muslim culture, and Ayurvedic refers to the analogous medical system in Hindu culture.

45 Saeed, "Ishtihar Tasveeren," 7. 
the fuss was about and to make sure their wives and daughters weren't being tainted by its content. Yusuf Dehlvi had developed a sort of divide-and-rule strategy: by fostering competition within Shama's subscribers' households, he ensured profits. I still remember snatching the magazine from my brothers and sisters, and having it snatched from me in turn.

\section{5}

\section{Conclusions}

Throughout its existence, Shama was designed to appeal to a wide readership and it assembled its far-flung subscribers into a virtual community, a thriving Urdu public: the "Bazm-e Shama." In its heyday, Shama had branches in Pakistan, Bangladesh, Afghanistan, England, and various cities in the Middle East. The expansion of Shama beyond India's borders is evidence that long after Independence, Urdu persisted as a transnational language, linking Urdu readers in India, Pakistan, and the diaspora. Moreover, Shama's pursuit of market share had several unintentional effects that made an impact on twentiethcentury Indian culture in significant ways. First, Shama sustained Urdu print culture despite the ascendance of government-sanctioned Hindi. Second, it resisted the Islamization of Urdu itself by including non-Muslim writers and making Urdu essential to discourses about film, popular culture, and modernity. Third, by linking cinema to literature and progressive writing, it enhanced the film industry's cultural capital and critical respect.

I have argued that despite stigmas and taboos, Shama was read by men, women, and young people alike-highbrow, middlebrow, and lowbrow. The "Bazm-e Shama" mirrored the filmi- 'ilmi formula of the magazine in combining a taste for poetry, an appreciation for progressive literature, and a fascination with the cosmopolitan world of the film industry. While readers' letters were often concerned with the cultural negotiation of modernity, debates about religion were virtually absent. Shama's cover paintings, participatory culture, and eclectic advertising all contributed to foster a notion of cosmopolitan modernity that was rooted in Indian Urdu culture but nevertheless challenged accepted norms of gender, religion, and taste.

The "Bazm-e Shama" was a significant sub-formation within the fragmented Urdu cosmopolis described by Dubrow. And like the Hindi public sphere described by Orsini, the "Bazm-e Shama" was a product of print culture. Both the Urdu language and the writing system were an integral part of this community's identity, and Shama motivated potential readers to learn Urdu even as it disappeared from formal educational channels. According to my own experience and other anecdotal evidence from Urdu-speakers who grew up 
during the 196os and 1970s, family subscriptions to Khilaunā, Shama, or Bāno made people feel that they belonged to a wider community of Urdu speakers, and that this in turn motivated them to learn to read the Urdu script. This understanding of Urdu as a consummately print language stands in distinction to the notion of Hindūstānī used by the earlier generation of progressive writers. For them, the emphasis was on content over form, and their works could be published in Nasta'līq, Nāgarī, or even Roman script. For Shama's readers, however, form and content were inseparable.

Our journey through the pages of Shama reveals several notable features of the post-Independence Urdu cosmopolis. First, the Shama era marked an important phase in the evolution of the cosmopolis, a phase that had emerged from the fractures of nationalism and communalism but not yet confronted the digitally mediated present described by Dubrow. ${ }^{46}$ Urdu had managed to assert its status as the primary language of film and popular culture in South Asia, but this had entailed a shift away from a literary elite to a largely middle-class Urdu readership. This readership was, however, more diverse and more tolerant than that of the earlier period, and more adaptive to post-Independence notions of national integration and transnational multicultural modernity.

Second, Shama is distinguished from other manifestations of the Urdu cosmopolis by its emphasis on visuality. Photographs of actress, sketches of women, cover paintings of women, advertisements featuring women-as argued above, all of these contributed to the scopophilia of the publication. But there is a more subtle effect at work in Shama's pages: the Urdu script itself, Nasta līq, is deployed in tandem with the images in a symbiotic way such that its sinuous curves acquire - by association or reflection - a certain feminine aesthetic. Inderjeet's illustrations blend visually with his title calligraphy, and the title calligraphy blends with the textual content that throughout Shama's publication history was produced by calligraphers $(k \bar{a} t i b)$ rather than set in type. Although Urdu is a language that in some contexts is meant to be heard and not seen, Shama foregrounds Nastalìq as the dominant vehicle for Urdu written expression. This perhaps explains why the parallel Hindi publications like Sushamā remained mere reflections of their more glamorous sisters.

Third, Shama was the terrain upon which various contradictions and paradoxes of modernity played out, particularly those surrounding religion and gender. I have discussed at length how Shama both objectified women and invested them with subjective agency, not only as readers, authors, and consumers, but also as wielders of the tirchhi nazar visualized on the covers. Meanwhile, Shama helped to articulate what might be called "Muslim modernism." This 
was a mode of negotiated identity based on language and history as much as on religion, and certain contradictions arose out of the negotiation process. For example, if Urdu is classed as a religious minority language within India's linguistic salad bowl, then its speakers may be perceived as constituting an ethnicity, thus becoming prey to communalism. On the other hand, if Urdu is a language of nostalgia, bearing a legacy of poetry and elitism, then it will be made obsolete by the surge of modernity. In Shama, though, we find that while Urdu inscribes both piety and nostalgia, it is perpetually reinvented as a cosmopolitan, secular, and inclusive language, deriving its organic power from the most modern of art forms, film.

Yusuf Dehlvi passed away in 1985 . With the death of the partriarch, the various Shama publications began competing against each other, ${ }^{47}$ even as the Urdu cosmopolis was disrupted by economic liberalization and globalization. To some extent, Shama's downfall was caused by the fact that it was Urdu-dependent and that Urdu readership was dwindling, but Shama's place was not taken by Hindi or English publications. Rather, radio and television emerged to do the work of bringing film news and reviews to the Indian public. With the advent of the internet, readership dwindled even more rapidly. Another set of factors for the decline of Shama derives from the family culture of the Dehlvi family itself. According to Mohsin Dehlvi, he and his siblings and cousins were kept away from the film world, exiled from the Urdu cosmopolis. ${ }^{48}$ Even as stars were staying at the family mansion in Delhi, the children were discouraged from watching Indian films or reading vernacular languages. The causes of Shama's demise were manifold: family politics, language and culture wars, internal and external competition, resources being spread too thin, the challenges of juggling a diverse portfolio of businesses, the advent of television and the internet, and the dwindling supply of new Urdu writers to replace those who had moved on after using Shama to achieve fame.

Shama shut down almost overnight in December 1999. The editors walked in one morning and said, "Enough, we're closing down." ${ }^{\text {"9 }}$ The workers had seen it coming. For the next twenty years, passers-by on Asaf Ali Road saw monkeys and tree branches peeping through the broken office windows. Most of the records in the office were lost or destroyed, except for a few small stacks of the last few issues scattered amidst the debris.

In the very first issue of Shama in 1939, the following couplet was used as an epigraph:

47 Personal communication from Mohsin Dehlvi, July 26, 2018.

48 Personal communication from Mohsin Dehlvi, July 26, 2018.

49 Personal communication from Mohsin Dehlvi, July 26, 2018. 
lo sham' hu'ì raushan àne lage parvāne

$\bar{a} \dot{g} h \bar{a} z$ to acchhà hai anjām ḳhudā jāne $e^{50}$

The candle is lit, the moths begin to arrive

A good beginning, God knows if it will survive

In the end, Shama was extinguished not so much by an abundance of moths, but rather by a convergence of inimical winds arising from the storm of modernity. The Urdu cosmopolis would persist in different guises, but never with the flair and power that it had in the golden age of Shama.

\section{Bibliography}

Abbasi, Yasir. "The Lost World of Urdu Film Magazines," The Hindu, January 12, 2019. https://thehindu.com/society/the-lost-world-of-urdu-film-magazines/article 25968853.ece.

Aḳhtar, Harī Chand. Kufr o İmān. Delhi: Union Printing Press, n.d. https://www.rekhta. org/ebooks/kufr-o-iman-hari-chand-akhtar-ebooks.

Allāhābādī, Akbar. Kullīyāt-e Akbar Allāhāāādì, vol. 1. Jaunpur: Mohsini Press, 1923.

Argyle, M., R. Ingham, F. Alkema, et al. "The Different Functions of Gaze." Semiotica 7 , no. 1 (1972): 19-32.

Bloom, James D. Reading the Male Gaze in Literature and Culture: Studies in Erotic Epistemology. Cham, Switzerland: Palgrave Macmillan, 2017.

Cardoza, Kavitha and Radhika Parameswaran. "Melanin on the Margins: Advertising and the Cultural Politics of Fair/Light/White Beauty in India." Journalism \& Mass Communication Monographs 11, no. 3 (2009): 213-74.

Choi, Hojoon, Tom Reichert, Kyunga Yoo, and Michael S. LaTour. "Do Feminists Still Respond Negatively to Female Nudity in Advertising?: Investigating the Influence of Feminist Attitudes on Reactions to Sexual Appeals." International Journal of Advertising 35, no. 5 (2016): 823-45.

Doctor, Vikram. "How Calendars Went from Featuring Gorgeous Women to Being Just Purely Functional," Economic Times, December 29, 2018. http://economictimes .indiatimes.com/articleshow/67293266.cms.

Dubrow, Jennifer. Cosmopolitan Dreams: The Making of Modern Urdu Literary Culture in Colonial South Asia. Honolulu: University of Hawai'i Press, 2018.

50 There is no attribution for this couplet in the magazine, and I have not been able to identify the author. 
Eck, Diana. Darśan: Seeing the Divine Image in India. Chambersburg, PA: Anima Books, 1981.

Habermas, Jürgen. The Structural Transformation of the Public Sphere. Cambridge, MIT Press, 1989 .

Huang, Ying and Dennis T. Lowry. "An Analysis of Nudity in Chinese Magazine Advertising: Examining Gender, Racial and Brand Differences." Sex Roles 66, no. 7-8 (2012): 440-52.

Inderjeet. "Afroz Taj in Conversation with Inderjeet 'Imroz."” By Afroz Taj. Filmed June 2012 in Jalandhar, Punjab. YouTube video, 35:10. https://www.youtube.com/ watch?v=VXgurjDRxqw.

Jain, Kajri. Gods in the Bazaar: The Economies of Indian Calendar Art. Durham: Duke University Press, 2007.

Kang, Mee-Eun. “The Portrayal of Women's Images in Magazine Advertisements: Goffman's Gender Analysis Revisited." Sex Roles 37, no. 11-12 (1997): 979-96.

Linhart, Zdenek and Christian Dianoux. "The Effectiveness of Female Nudity in Advertising in Three European Countries." International Marketing Review 27, no. 5 (2010): 562-78.

Majeed, Javed. "Narratives of Progress and Idioms of Community:Two Urdu Periodicals of the 1870 ." In Negotiating India in the Nineteenth-Century Media, edited by David Finkelstein and Douglas M. Peers, 135-63. London: Macmillan Press Ltd., 2000.

Minault, Gail. Secluded Scholars: Women's Education and Muslim Social Reform in Colonial India. Delhi: Oxford University Press, 1998.

Mukherjee, Debashree. "Creating Cinema's Reading Publics: The Emergence of Film Journalism in Bombay." In No Limits: Media Studies from India, edited by Ravi Sundaram, 165-98. New Delhi: Oxford University Press, 2013.

Mukherjee, Debashree. "Notes on a Scandal: Writing Women's Film History against an Absent Archive." BioScope 4, no. 1 (2013): 9-30.

Mulvey, Laura. "Visual Pleasure and Narrative Cinema." Screen 16, no. 3 (Autumn 1975): 6-18. https://doi-org.libproxy.lib.unc.edu/10.1093/screen/16.3.6.

Orsini, Francesca. The Hindi Public Sphere 1920-1940: Language and Literature in the Age of Nationalism. New Delhi: Oxford University Press, 2002.

Orsini, Francesca. Print and Pleasure: Popular Literature and Entertaining Fictions in Colonial North India. Ranikhet: Permanent Black, 2009.

Paek, Hye-Jin and Michelle R. Nelson. "Cross-Cultural Differences in Sexual Advertising Content in a Transnational Women's Magazine." Sex Roles 53, no. 5 (2005): 371-83.

Pinney, Christopher. Photos of the Gods: The Printed Image and Political Struggle in India. New Delhi: Oxford University Press, 2004.

Rajagopal, Arvind. The Indian Public Sphere: Readings in Media History. New Delhi: Oxford University Press, 2oog. 
Saeed, Yousuf. "Ishtihar Tasveeren:Visual Culture of Early Urdu Magazines." ArtConnect 7, no. 2 (July-December 2013), 4-20. http://tasveergharindia.net/essay/ishtihar -tasveeren-early-magazine-urdu.html.

Siddiqui, N. "Who Reads Urdu Women's Magazines and Why?: An Investigation of the Content, Purpose, Production and Readership of Urdu Women's Digests." International Journal of Media \& Cultural Politics 8, no. 2 (2012), 323-34.

Uberoi, Patricia. "Chicks, Kids and Couples: The Nation in Calendar Art," India International Centre Quarterly 29, no. 3/4 (Winter 2002-Spring 2003), 197-210. https://www.jstor.org/stable/23005826.

Uberoi, Patricia. "Feminine Identity and National Ethos in Indian Calendar Art," Economic and Political Weekly 25, no. 17 (April 28, 1990), WS41-48. https://www.jstor .org/stable/4396224.

Witkowski, Tomasz. "Thirty-Five Years of Research on Neuro-Linguistic Programming. NLP Research Data Base. State of the Art or Pseudoscientific Decoration?" Polish Psychological Bulletin 41, no. 2 (2010): 58-66. 